\title{
京都市および近郊の住宅におけるエネルギー消費量と 居住者の意識・住まい方に関する調査研究 \\ INVESTIGATION ON THE RESIDENT'S CONSCIOUSNESS, LIFE STYLE AND ENERGY CONSUMPTION OF HOUSES IN AND AROUND KYOTO CITY
}

\author{
大和 義昭*1, 松 原 斎樹*2, 藏 澄 美仁*3 \\ Yoshiaki YAMATO, Naoki MATSUBARA and Yoshihito KURAZUMI
}

\begin{abstract}
The purpose of this paper is to clarify the difference in the resident's consciousness and life style which affects the increases of energy consumption in summer and winter in houses in and around Kyoto city. Energy consumption, resident's consciousness and life style were investigated.

The results were as follows:

1. Energy consumption of the investigated houses is $49.3 \mathrm{GJ} /$ year. Resident's consciousness affect the seasonal increase in energy consumption.

1. Resident's consciousness has influenced energy conservation. The resident is doing energy conservation, doing devising a life style.

1. The group whose increase of energy consumption were low in summer refrained from air conditioning and utilize ventilation positively. The group whose increase of energy consumption were low in winter refrained from heating and clothed thickly. These groups are doing much more devices in their life.
\end{abstract}

Keywords: house, resident, consciousness, life style, energy consumption

住宅, 居住者, 意䪭, 住まい方, エネルギー消費量

\section{1. はじめに}

地球温暖化問題の点から，エネルギー消費量を抑制することの重 要性が增している．エネルギー消費量抑制の対策を考えるためには, 先ずエネルギー消費実態を定量的に把握しておく必要がある．住宅

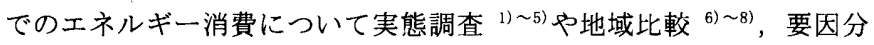
析 ${ }^{9)}$ 10)を行った研究は多くあるが，これらは居住者の意識・住ま い方をあまり重視していない。建築環境工学分野では意識・住まい 方はあまり研究対象とされてこなかったが，90 年代以降その試みが 徐々に行われるようになった. 松原ら ${ }^{11) \sim(4)}$ は, 「暖房器具の使用を 控えているため寒さを感じ, 快適とはいえないが, 省エネルギーな ので満足している」という場合があるように，居住者の意識により 温熱環境への要求度に違いがあり，冷暖房機器の使用状況や寒暑を 避ける工夫等の住まい方には大きな違いがあることを指摘している. したがって, 住宅のエネルギー消費量について考察する際, 居住者 の意識・住まい方を考慮することも重要である.

政府も地球温暖化防止の観点から省エネルギー的な住まい方へ 移行しょうと取り組みを強めつつある ${ }^{15)}$ ．住まい方とエネルギー 消費について寒冷地や積雪地の住宅を対象とした研究 ${ }^{16) ~ 211}$ は多い が関東以西の温暖地の住宅を対象にした研究は少ない.澤地ら ${ }^{222 ~ ~}$
${ }^{24)}$ は関東地方の戸建, 集合住宅を対象にして, 室内温熱環境と居住 者の生活行為, 在室場所, 冷暖房行為の関係を示した。 また, 洪 ${ }^{25)}$ は東京都およびその周辺の集合住宅を対象にしてェネルギー消費 の要因分析を行い, 冷暖房器具使用状況や入浴状況などがエネルギ 一消費に及ぼす影響について検討した。しかし，これらは居住者の

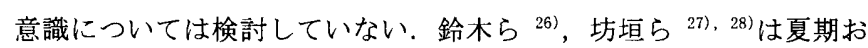
よび冬期の住まい方・環境意識とエネルギー消費について全国的な 調査を行った。しかし, 考察の重点はエネルギー消費実態や冷暖房 器具使用時間などについての地域間の比較検討におかれている．福 島ら ${ }^{29)}$ は福岡市の戸建, 集合住宅を対象とした調査を行い, 平日 と休日との比較から, エネルギ一消費は居住者の生活行為の影響が 大きいことを示した. しかし，生活者の意識について検討しておら ず，また，エネルギー消費量は夏期の 1 日分についての検討である. 佐々ら ${ }^{30}$ は奈良市近郊の戸建住宅を対象とした調査で, 扂住者を 省エネルギー重視, 快適性重視, どちらも重視の 3 グループに分類 し, グループ間の夏期の泠房器具使用状況と光熱費支出額の違いを 示した。しかし，エネルギー消費を定量的に比較しておらず，また， 灯油については調査していない.

夏期は主として冷房の使用により，また，冬期は主として給湯
*1 侏くろがね工作所 修士 (生活科学)

*2 京都府立大学人間環境学部環境デザイン学科 教授・工博

*3 京都府立大学人間環境学部環境デザイン学科 助教授・工博
Kurogane Kosakusho Ltd., M. Living Science

Prof., Dept. of Environmental Design, Kyoto Pref. University, Dr. Eng.

Assoc. Prof., Dept. of Environmental Design, Kyoto Pref. University, Dr. Eng. 
用および暖房使用により，春，秋期よりエネルギー消費量が增加す る傾向がある．今後住宅での省エネルギーにとって夏期の泠房用， および冬期の給湯・暖房用エネルギー消費量を抑制することは不可 欠であり, 居住者の意識・住まい方と夏期・冬期のエネルギー消費 增加量に関する知見は貴重な資料となる. しかし，居住者の意識や 住まい方と夏期・冬期のエネルギー消費增加量について考察した研 究はほとんどない，森ら ${ }^{31}$ は近畿圈内の太陽光発電，全電化， 般の戸建住宅を対象にした調査から，居住者の節約行為の実施率と 年間総エネルギー消費量との関係を示した。しかし，夏期，冬期の 春，秋期に対するエネルギー消費増加量には着目していない，

従来, 住宅のエネルギー消費量について, 町家や農家, 太陽熱 利用空気集熱床暖房住宅は十分に調査されているとはいえない。町 家や民家の夏期や冬期の室内温熱環境を対象にした研究はある 32)33)が，エネルギー消費量に関する知見は少ない。太陽熱利用空気 集熱床暖房住宅は自然エネルギーを利用して電気やガス，灯油の消 費を抑える効果があると期待されており，エネルギ一消費量実態の 調査が行われている ${ }^{34)}$ ） 35). しかし，年間総エネルギー消費量デー 夕の蓄積はまだ十分とはいえず，また，夏期および冬期のエネルギ 一消費增加量についてはこれまでほとんど調査されていない，

以上のように，温暖地の住宅のエネルギー消費と居住者の意 識・住まい方との関連についての研究は少なく, また, 居住者の意 識や住まい方と夏期・冬期のエネルギー消費增加量について検討し た研究はほとんどない.

本研究の目的は, 住宅のエネルギー消費量と居住者の意識・住 まい方の実態を明らかにし，夏期・冬期のエネルギー消費増加量に 影響を及ぼす意識・住まい方の違いを明らかにすることである。調 査は京都市および近郊地域の一般的な戸建, 集合住宅と, さらに高 気密・高断熱住宅, 町家, 農家, 太陽熱利用空気集熱床暖房住宅を 対象にした。本研究はこれまであまり調査されていない形式の住宅 を対象に含めたことが特徵であり，得られた知見は温暖地における 省エネルギ一的な住まい方を考えていく上での資料として意義があ る。

\section{2. 調査概要}

\section{1. 調查内容}

調查は，対象住宅に訪問してアンケート用紙を配布・回収する 方法により実施した。調査対象住宅は，都心分譲集合住宅（以下 $\mathrm{TN}$ ），都心賃貸集合住宅（以下 $\mathrm{SD}$ ），郊外戸建旧省エネルギー基準 対応住宅 (以下 JM), 都心戸建住宅（以下 $\mathrm{NJ}$ ), 郊外農家住宅（以 下 YS), 高断熱-高気密住宅 (以下 YN), 太陽熱利用空気集熱床暖 房住宅（以下 SH）の 7 種の住宅種別から選定した。アンケート調 查の内容を Table 1 に示す. エネルギー消費量の調査は居住者に電 気, ガス, 灯油の使用量と料金の記入を依頼したが; 電気とガスに ついては，居住者の同意書を得た上で，供給業者から使用量データ の提供を受けた。エネルギー消費量のデータは 1995 年 7 月から 1997 年 5 月までを収集した：調查は 1996 年 8 月（夏季）と 1997 年 2 月（冬季）に行った。 冬季調査は, 夏季調查をした世帯の中か ら承諾を得られた世帯を対象に行った。また，一部の世帯に対して， 住まい方や間取り, 家具配置, 温熱環境の実態を詳細にわたって観 察するため, ヒアリング調査並びに主な居室の室温の実測調査を行

\begin{tabular}{|c|c|c|c|c|c|c|c|c|}
\hline & TN & SD & $J M$ & $\mathrm{NJ}$ & YS & YN & SH & 合許 \\
\hline \multicolumn{9}{|l|}{ 配布（君） } \\
\hline 夏季 & 31 & 28 & 28 & 30 & 39 & 12 & 21 & 189 \\
\hline 冬季 & 22 & 24 & 24 & 26 & 29 & 11 & 13 & 149 \\
\hline 調查時期 & \multicolumn{8}{|c|}{$\begin{array}{l}\text { 夏季 : 1996年8月 } \\
\text { 冬季 : 1997年2月 }\end{array}$} \\
\hline 䯏査項目 & \multicolumn{4}{|c|}{$\begin{array}{l}\text { 家模構成，家族全員の年齢 } \\
\text { 主宅の構造，床面積，築年数 } \\
\text { 月毎の電気，ガス，灯油使用量 } \\
\text { 電気，ガス，灯油の節約の意識 }\end{array}$} & \multicolumn{4}{|c|}{$\begin{array}{l}\text { 塞暑を避けるためのエ夫 } \\
\text { 夏期, 冬期の居間の温熱環境 } \\
\text { 理想的な冷・暖房環境 } \\
\text { 泠・䁔房器具, 電化製品使用状況 }\end{array}$} \\
\hline
\end{tabular}

\begin{tabular}{|c|c|c|c|c|c|c|c|}
\hline & $\mathrm{TN}$ & SD & $\sqrt{11}$ & NJ & YS & YN & $\mathrm{SH}$ \\
\hline 住宅形息 & 藮合 & 䔩合 & 户建 & 戶建 & 可建 & 市建 & 户建 \\
\hline 権造 & $\mathrm{RC}$ & RC & 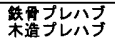 & 在来木遀 & 在来木遀 & $\begin{array}{r}2 \times 4 \\
\text { 木造プレハフ }\end{array}$ & 在来木道 \\
\hline 立地 & 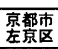 & 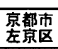 & 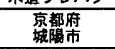 & $\begin{array}{c}\text { 京敖市 } \\
\text { 茜陣 }\end{array}$ & 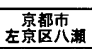 & 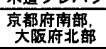 & 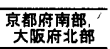 \\
\hline 特徽的な事項 & - & - & 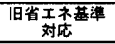 & 町家 & 農家 & 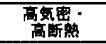 & 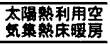 \\
\hline 平均床面皘 $\left(\mathrm{m}^{2}\right)$ & 67.3 & 60.0 & 108.0 & 118.9 & 162.5 & 187.2 & 118.9 \\
\hline 平的䇣年数（年） & 15.5 & 5.4 & 8.8 & 73.5 & 72.8 & 3.9 & 2.3 \\
\hline 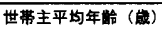 & 52.2 & 42.7 & 39.0 & 64.8 & 49.7 & 36.6 & 30.5 \\
\hline 格正家族人数 $*$ (人) & 2.8 & 2.9 & 4.4 & 2.7 & 4.3 & 4.5 & 4.3 \\
\hline
\end{tabular}

った.

\section{2. 調查対象住宅の特徵}

調查対象の住宅種別の概要を Table 2 に示す．各住宅種別の特徽 を以下に記す。

TN と SD はいずれも京都市左京区の市街地に建つ RC 造の集合住 宅である. 築年数が浅く，SD の方が TN よりも厚い断熱施工されて いるが，どちらも関西地域の集合住宅として一般的といえる．TN と SD のどちらも平均家族人数が少なかった. SD では世帯主が若く 子供が少ない世帯が多かったのに対して，TN では世帯主の年齢が 高く子供が独立して家を離れている世帯が多かった。JM は京都府 城陽市の新興住宅地に建つ鉄骨造および木造の戸建住宅であり，ど の世帯も旧省エネルギー基準を満たしている．世帯毎の建物の仕様 (使用建材や断熱施工法等) や床面積などのばらつきが少なかった. JM では, 40 歳代の夫婦と子供 1〜2人の世帯が多かった. NJ は京 都市上京区西陣に建つ町家である。平均築年数が調查対象の住宅種 別の中で最も古い，いくつかの世帯では若干の増改築をしているが， 断熱・気密施工された世帯はなかった，NJ では，高齢の夫婦で暮 らしている世帯が多かった．YS は京都市左京区八瀨の戸建住宅で ある、構造は木造在来工法で，和室の続き間や座敷，縁側を備える など農家型の住宅の特徽を持っている. 平均築年数は約 72.8 年と 古く，中には築 100 年を超える住宅もあった．NJ と同様に，一部 の世帯では若干の増改築をしているが，どの世帯も断熱・気密施工 されていない，居住者の構成では，40〜50 歳代の世帯主に子供 2 人の世帯と，世帯主が 60 歳代で三世代同居世帯の二つのタイプが 目立った。YN は京都市を含む京都府南部と大阪府北部に建つ枠組 壁工法や木造パネル式工法の戸建住宅である．平均床面積が調査対 象の住宅形式の中で最も広かった，尚，本研究では建物の熱損失係 数や相当隙間面積を計測していないため, 高気密・高断熱とは住宅 供給業者の認識である。しかしながら，省エネルギー基準を大きく 上回る断熱施工していることや，気密性の高いサッシと複層ガラス の使用等から，YNの断熱・気密性能は他の住宅形式と比較してか なり高いと考えられる. YN では，40～50 歳代の世帯主に子供 2〜3 人の世帯が目立った。 SH は京都市を含む京都府南部と大阪府北部 に建つ戸建住宅である，平均築年数が調査対象の住宅種別の中で最 
も浅い、また，家族の平均年齢が最も若かった，世帯主のほとんど が 40 歳代で, また, 10 歳未満の子供の人数が最も多かった. 本研 究では, 全対象住宅が京都府南部から大阪府北部の比較的まとまっ た地域にあったため，気象条件はほぼ同一として扱った。

\section{3. 結果}

\section{1. 住宅種別のエネルギー消費量}

アンケート調査用紙の回収数を Table 3 に示す．採集したエ ネルギー消費量データのうち，久損が最も少ない 1996 年 3 月から 1997 年 2 月までの一年間分を解析に用いた注)。電気，ガス，灯油 の使用量データは Table 4 の数值を用いて二次エネルギー消費量に 換算した。電気，ガス，灯油の消費量を合計したものを総エネルギ 一消費量とする．Fig．１に住宅 1 戸当たりの年間総エネルギー消 費量を示す

\begin{tabular}{|c|c|c|c|c|c|c|c|c|c|c|c|}
\hline & TN & $\overline{S D}$ & $\sqrt{M}$ & NJ & $\overline{Y S}$ & $\overline{Y N}$ & SH & 合計 & 電気 & 3.6 & $\mathrm{MJ} / \mathrm{kWh}$ \\
\hline 回収 (局) & & & & & & & & & 都市ガス & 46.1 & $\mathrm{MJ} / \mathrm{m}^{3}$ \\
\hline 夏委 & 22 & 24 & 26 & 24 & 29 & 11 & 13 & 149 & プロパンガス & 100 & $\mathrm{MJ} / \mathrm{m}^{3}$ \\
\hline 冬季 & 20 & 19 & 24 & 18 & 6 & 7 & 7 & 101 & 灯油 & 37.3 & $\mathrm{MJ} / \mathrm{L}$ \\
\hline
\end{tabular}
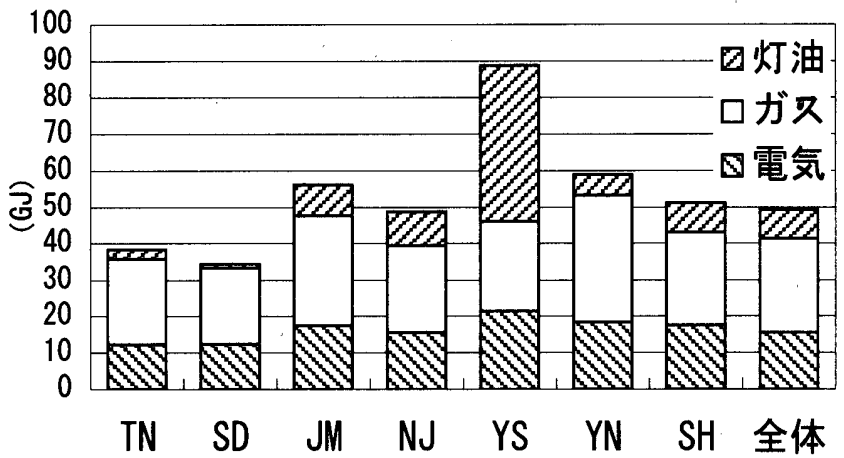

Fig. 1 住宅1戸当たりの年間総エネルギー消費量

全調查住宅の平均年間総エネルギー消費量は $49.3 \mathrm{GJ} /$ 年・戸て あった．住宅種別では，TN は $38.3 \mathrm{GJ} /$ 年・戸，SD は $34.5 \mathrm{GJ} /$ 年・ 戸，JM は約 $56.4 \mathrm{GJ} /$ 年・戸， NJ は約 $48.9 \mathrm{GJ} /$ 年・戸，YS は約 $88.9 \mathrm{GJ} /$ 年・戸，YN は約 $59.0 \mathrm{GJ} /$ 年・戸，SH は約 $51.3 \mathrm{GJ} /$ 年・戸 であった。また，集合住宅の平均年間総エネルギー消費量は $36.4 \mathrm{GJ} /$ 年・戸，戸建住宅の平均年間総エネルギー消費量は $57.3 \mathrm{GJ} /$ 年・戸であった．YS の年間総エネルギー消費量が最も多 く, 集合住宅の $\mathrm{TN}, \mathrm{SD}$ が少なかった。住宅種別により年間総工 ネルギー消費量が異なる結果となった。特に，最も多いYS は， 最も少ないSDの約 2.6 倍もあり，また，“YS に次いで 2 番目に多 いYN と比較しても約 1.5 倍多い結果となった。 エネルギ一種別 でみると，YS では灯油の消費量が多く，YS 以外ではガスの消費 量が最も多かった。

本研究の住宅一戸当たりの年間総エネルギー消費量は，京都の 戸建，集合住宅を調査した既往研究 ${ }^{36)}$ の年間エネルギー消費量 より多かった．また，本研究の戸建住宅の年間総エネルギー消費 量は，関西地区を対象にした森ら ${ }^{311}$ の一般住宅の年間エネルギ 一消費量とほぼ等しい結果となった。

住宅種別の床面積当たりの平均年間総エネルギー消費量は, $\mathrm{TN}$ は $0.56 \mathrm{GJ} /$ 年・ $\mathrm{m}^{2}, \quad \mathrm{SD}$ は $0.62 \mathrm{GJ} /$ 年・ $\mathrm{m}^{2}, \mathrm{JM}$ は $0.55 \mathrm{GJ} /$ 年・ $\mathrm{m}^{2}, \mathrm{NJ}$ は $0.49 \mathrm{GJ} /$ 年・ $\mathrm{m}^{2}, \mathrm{YS}$ は $0.79 \mathrm{GJ} /$ 年・ $\mathrm{m}^{2}, \mathrm{YN}$ は $0.32 \mathrm{GJ} /$ 年・ $\mathrm{m}^{2}, \mathrm{SH}$ は $0.47 \mathrm{GJ} /$ 年・ $\mathrm{m}^{2}$ ，全体では $0.54 \mathrm{GJ} /$ 年・ $\mathrm{m}^{2}$ であった。
YS が最も多く, YN が最も少なかった。

住宅種別の修正家族人数 ${ }^{36)}$ 当たりの年間総エネルギー消費量は, $\mathrm{TN}$ は $15.3 \mathrm{GJ} /$ 年・人, $\mathrm{SD}$ は $15.4 \mathrm{GJ} /$ 年・人，JM は $13.2 \mathrm{GJ} /$ 年・人， $\mathrm{NJ}$ は $19.1 \mathrm{GJ} /$ 年・人，YS は $20.6 \mathrm{GJ} /$ 年・人，YNは $15.8 \mathrm{GJ} /$ 年・人， $\mathrm{SH}$ は $13.7 \mathrm{GJ} /$ 年・人で，全体では約 $16.1 \mathrm{GJ} /$ 年・人であった．YS が最も多く, NJ が最も少なかった.

\section{2. 居住者の意識・住まい方の実態}

夏期，冬期それぞれの電気，ガス，灯油の節約の実行について の結果をFig. 2, Fig. 3 に示す.

冬期は電気，ガス，灯油のいずれも節約している割合が大きか ったが，夏期はガスと灯油を節約している割合が小さかった．住宅 種別では，JM は夏期および冬期の電気，ガス，灯油を「節約して いない」割合が大きかった（JM：全体平均（\%), 夏電気 24.1: 9.5, 夏ガス $89.7: 87.8$, 夏灯油 $57.1: 47.9$, 冬電気 $16.7: 5.0$, 夏灯油 $38.9: 20.4$, 冬灯油 $31.6: 13.1)$. SH は全世帯が夏期のガ スを節約していた，夏期のガスを「節約している」世帯のほとんど はSH であり，他の住宅種別で夏期のガスを「節約している」世帯 は少数であった（SH 72.2\%，JM 16.6\%，YS 11.1\%).SH では太 陽熱による温水を利用することで給湯用のエネルギー消費が抑えら れるために，居住者の「節約している」認識が強くなったと考えら れる．また，夏期の灯油は NJ，YS，SH で「節約している」割合が 大きく,JM と YN は小さかった（NJ 76.9\%，YS 65.2\%，SH $54.5 \%, J M 33.3 \%$, YN 20.0\%)。夏期のガス，灯油を節約しない 理由は，「快適で便利な生活に支障をきたす」（夏ガス $48.1 \%$ ，夏 灯油 $57.7 \%$ ）と「節約しようと思うが面倒」(夏ガス $33.3 \%$ ，夏灯
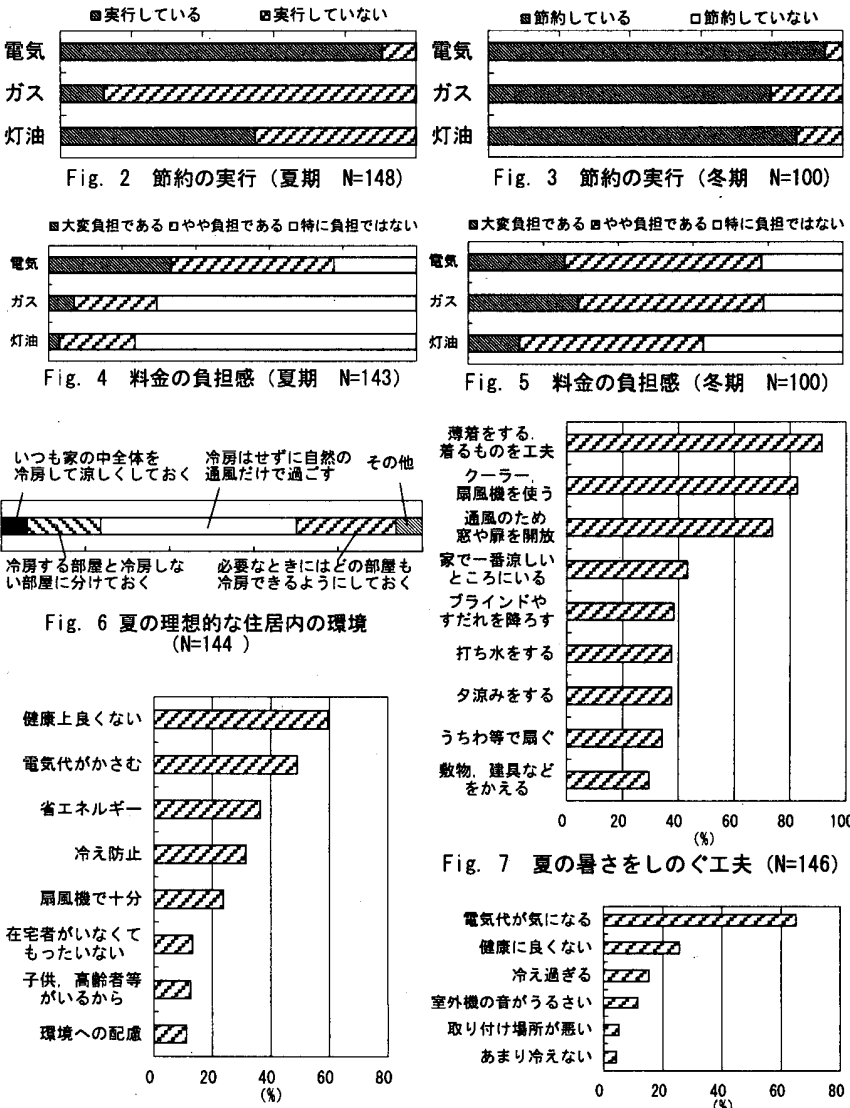

Fig. 8 冷房を控える理由（N=143）

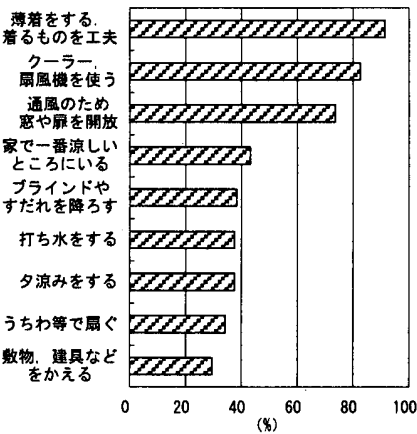

Fig. 7 夏の㟟さをしのぐエ夫 $(N=146)$

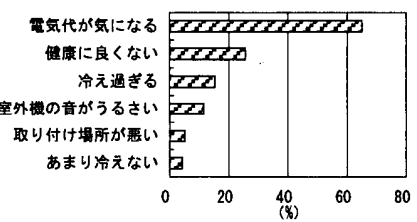

Fig. 9 冷房時に感じる不満 $(N=137)$ 


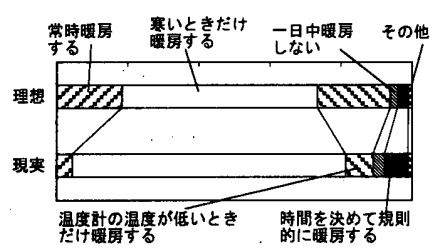

Fig. 10 理想的な暖房時間 $(N=91)$

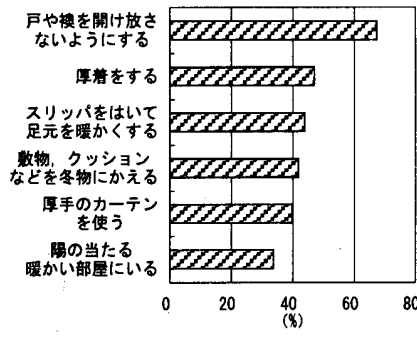

Fig. 12 寒さをしのぐためのエ夫 $(\mathrm{N}=98$

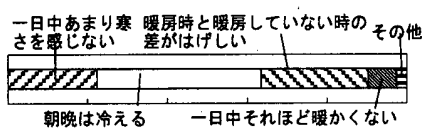

Fig. 14 居間の室温変化 $(\mathrm{N}=98)$

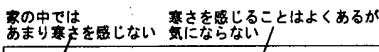

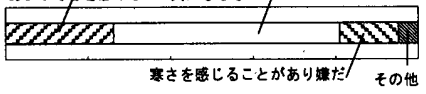

Fig. 16 冬期に家の中の寒さについて ( $\mathrm{N}=98)$

油 19.2\%).が多かった. また, 夏期のガス, 灯油の料金について 「特に負担ではない」が多かった（Fig．4）。家庭内の電化製品の 使用状況から, 夏期のガス, 灯油の用途はほぼ調理と給湯（風呂の 追い炊きを含む）に限られていた，夏期では暖房での消費がなくな り, 水温も上昇する。 そのため, ガス, 灯油の消費量は年間で最も 少なくなり，料金の負担感も減少する.そして，利便性などの理由 から，現状のガスおよび灯油の消費量は妥当であると見なされて， その結果，節約の意識が低下していると考えられる。

一方, 夏期の電気はほとんどの世帯で節約していた。ほとんど (96\%) の世帯で泠房の使用を控えていた. また，夏期の理想的な 室内環境は「冷房はせずに自然の通風だけで過ごす」が最も多かっ た（Fig. 6). そして，多くの世帯で夏の暑さをしのぐために「ク ーラー・扇風機の使用」する他に「薄着」や「通風のために空や扉 を開放」など住まい方を工夫していた（Fig，7）．冷房を控える理 由には「健康によくない」と「電気代がかさむ」が多かった（Fig. 8)，冷房時に感じる不満は「電気代が気になる」が最も多く，次い で「健康に良くない」が多かった（Fig．9）。これらのことから， 夏期には経済面と健康面の配慮から冷房を控え, 着衣や通風などの 住まい方を工夫して，電気を節約していると考えられる.

冬期の暖房について, 理想とする暖房時間は「寒いと感じたと きだけ」が最も多く, 次いで「温度計の温度が低いときだけ」,「常 時」が多かった（Fig. 10）。住宅種別にみると，YNで「常時」が 多かった（YN=75.0\%, 全体平均=18.3\%).一方, 害際に暖房して いる時間は，「常時」と「温度計の温度が低いときだけ」が少なく，

「寒いと感じたときだけ」が多かった。ほとんどの世帯で暖房時間 を限定していた。理想とする暖房範囲は, 約半数の世帯が「家の中 全体」であった。しかし，実際に「家の中全体」を暖房している世 帯はごく少数に限られており；ほとんどの世帯では「良くいる部屋
だけ」暖房するか，「(こたつ・ホットカーペットで）体の周囲だけ を採暖」していた（Fig. 11）。また，次節で述べるように「家の中 全体」を暖房しているのはほとんど SH であり，SH 以外で「家の中 全体」を暖房しているのは, 比較的断熱・気密性が高い JM と YN に 1 世帯ずつあるのみであった。 冬期には SH を除いたほとんどの世 帯で暖房範围を限定していた。そして，寒さをしのぐため「戸や襖 を開け放さない」や「厚着」などの住まい方を工夫していた（Fig. 12）。また，暖房が必要と感じる時は，家族でだんらんする時より も「来客時」が多かった（Fig. 13），京都では暖房の使用が倹約的 であることは既に指摘されている ${ }^{26)}$ が，本研究は同様な結果とな った。また，JM と YN で暖房範囲が限定されていた結果は，温暖地 においては住宅の断熱・気密性が高くなっても居住者は必ずしも全 室暖房をするわけではないこと ${ }^{37)}$ を裏づける結果となった。

暖房の使用が限定的であるため, 冬期の室内温熱環境は快適域 よりも低温であると考えられる。鈴木ら ${ }^{26)}$ ，松原ら ${ }^{14)}$ は，冬期の 居室の室温は快適域よりもかなり低温に分布していることを指摘し ている，アンケート調查結果から，「一日中あまり寒さを感じな い」世帯は少なく $(22.3 \%)$, 多くの世帯で寒さを感じていた （Fig. 14）。また，暖房時の居間であっても 4 割以上の世帯で寒さ を感じていた（Fig. 15）。しかし，半数以上の世帯で「冬季に家の 中で寒さを感じることがあるが気にならない」とした（Fig. 16）. 冬期には，室内で寒さを感じていながら，倹約的な意識から暖房を 控えて，その一方で着衣など住まい方を工夫して，電気，ガス，灯 油の節約をしていると考えられる.

\section{3. 住宅種別のエネルギー消費量の季節变動と冷暖房器具使用時} 間

住宅種別の総エネルギー消費量の年間変動を Fig. 17 に示す. 住宅種別の冷・暖房器具使用時間を Table 5 に示す.

全ての住宅種別で，1月の総エネルギー消費量が最多となった. また, YS 以外の住宅種別で 7 月の総エネルギー消費量が前後の月

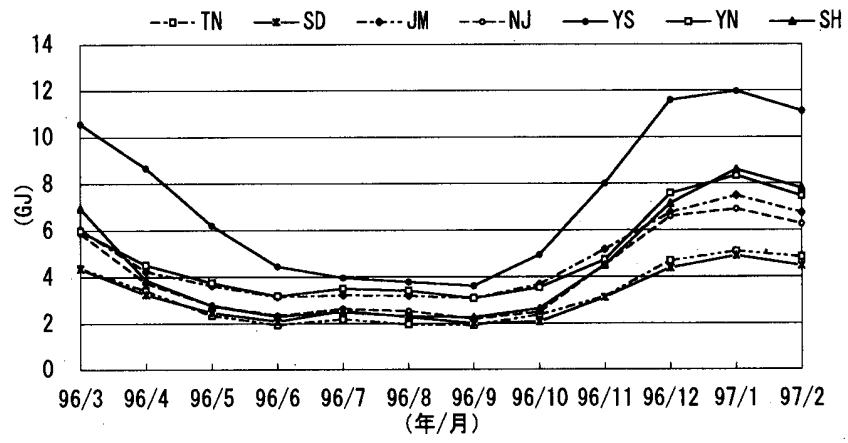

Fig. 17 総エネルギー消費量の年間変動

Table 5 冷 · 暖房器具使用時間

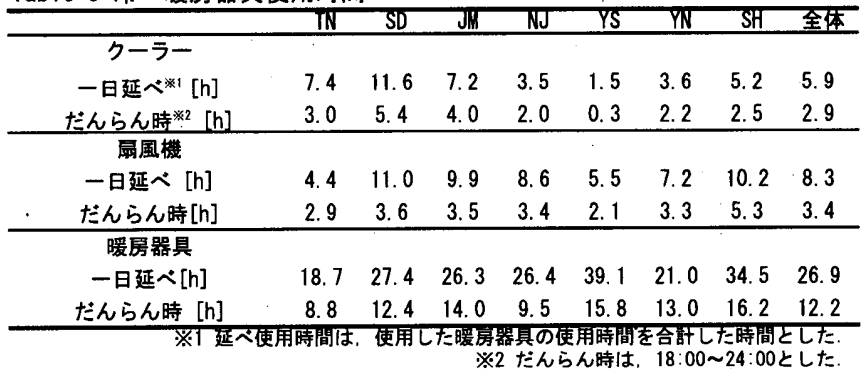


より多く，夏期のエネルギー消費量の増加がみられた，集合住宅の $\mathrm{TN}$ と SD は, 戸建の住宅種別群と比較して, 夏・冬期のエネルギー 消費量の増加が少なかった。 TN と SD の冷・暖房器具の使用時間 が，他の戸建の住宅種別群よりも短いとは言えなかった．アンケー 卜調查結果からは，集合住宅の TN と SD で戸建住宅より夏・冬期の エネルギー消費量の増加が小さい原因を明確に示すことはできなか った. TN と SD は RC 造であるため, 比較的断熱・気密性が高く， そのため冷暖房負荷が小さかったことが原因の一つと考えられる. YS の年間総エネルギー消費量は全住宅種別の中で最も多く，特に 冬期の增加が著しかった. YS では 1 日延べ暖房器具使用時間が最 も長かった。.また，だんらん時（18〜24 時）での比較でも，SHに 次いで暖房器具使用時間が長かった. YS では冬期の室温状況は,

「暖房している時としていない時の差が大きい」世帯が多かった (YS $66.7 \%$ ，全体平均 $30.6 \%$ )，YS では断熱・気密性が低いた め，暖房を止めると室温がかなり低下するので，やむなく暖房器具 使用時間が長くなっていると考えられる．また，YS では，冬期の 家の中で「寒さを感じることがあり，嫌だ」とする世帯が最も多か った（YS $41.7 \%$ ，全体平均 16.3\%)。これは全体では「感じるこ とはあるが，気にならない」が $53.1 \%$ で最も多かったこととは異 なる傾向であった．YS では，住宅の断熱・気密性が低いために暖 房器具使用時間が長くなり，冬期のエネルギー消費量が大きく增加 したと考えられる．SH は，秋期でエネルギー消費量が最少の 9 月 に対する冬期の增加率が大きかった．SH は太陽熱を給湯や暖房に 利用できるためエネルギー消費量が少ないことが予想されたが，実 態は異なっていた，アンケート調査から，SH は他の住宅種別より も「家の中全体を暖房」する傾向が強かった（SH $83.3 \%$ ，全体平 均 $41.4 \%$ ). また, 暖房器具の使用時間が長かった (Table 5). SH は，太陽熱で暖めた空気を家全体に循環させるため，吹き抜け 等で住宅内部が開放的な空間構成であった。冬期の蛋天時には太陽 熱以外に補助的に暖房器具を使用するが，住宅内部が開放的な空間 構成であるため暖まりにくく，暖房器具の使用時間が長かった。SH では，居住者の意識・住まい方と住宅の空間構成に影響されて，冬 期のエネルギー消費量が大きく増加したと考えられる．JM、YN は 春期から秋期にかけてのエネルギー消費量が YS に次いで多かった. JM はクーラーの使用時間が戸建住宅の中で最も長かった。 また, JM と YN では,「クーラーは必要」とする割合が多かった $(\mathrm{YN}=100 \% 、 \mathrm{JM}=96.4 \%$, 全体平均 $=82.3 \%)$. JM と $\mathrm{YN}$ では, クー ラーへの依存が比較的強いため，夏期の冷房用エネルギー消費量が 多いと考えられる．NJ は戸建住宅の中では一年を通じてェネルギ 一消費量が最も少なかった．NJ はだんらん時の暖房器具使用時間 が最も短く，夏期のクーラー使用時間はYS に次いで短かった。

\section{4. 夏期および冬期のエネルギー消費増加量と意識・住まい方}

節約行為と年間総エネルギー消費量は対応していることは指摘 されている ${ }^{31}$ ) が，意識・住まい方が夏・冬期のエネルギー消費増 加量に及ぼす影響についてはこれまでほとんど明らかにされていな い，前章では住宅種別に夏・冬のエネルギー消費量の増加と居住者 の冷暖房に対する意識と冷暖房器具使用時間について検討した．本 章では全調查住宅の夏期・冬期のエネルギー消費增加量を求め, 夏 期・冬期のエネルギー消費增加量が多かった住宅群と少なかった住
宅群とを抽出し，それらのグループ間の居住者の意識・住まい方の 違いを明らかにする.

\section{1. エネルギー消費増加量の大小による調査対象の分類}

夏期のエネルギー消費増加量は，7，8 月の電気エネルギー消費 量の平均値から 6,9 月の電気エネルギー消費量の平均值を差し引 いて算出した，そして，夏期のエネルギー消費增加量により夏期調 查住宅を住宅種別毎に分析した。分析はクラスター分析（Ward 法）とした．先ず，得られた樹形図から調査住宅を 3 つのクラスタ 一に類型化した．次に，各クラスターの平均エネルギー消費増加量 を算出した。 そして，平均エネルギー消費増加量が最多のクラスタ 一に属している世帯を夏期のエネルギー消費增加量が多かった住宅 群（以下，「夏期多い住宅」）, 最少のクラスターに属している世帯 を夏期のエネルギー消費増加量が少なかった住宅群（以下，「夏期 少ない住宅」）として抽出した。冬期のエネルギー消費増加量は, $12 １$ 月の総エネルギー消費量の平均值から 6,9 月の総エネルギ 一消費量の平均值を差し引いて算出した．冬期のエネルギー消費増 加量が多かった住宅群（以下，「冬期多い住宅」），冬期のエネルギ 一消費増加量が少なかった住宅群（以下，「冬期少ない住宅」）は, 夏期の場合と同様の方法で抽出した. Table 6 に「夏期多い住宅 数」と「夏期少ない住宅数」を示す. Table 7 に「冬期多い住宅」
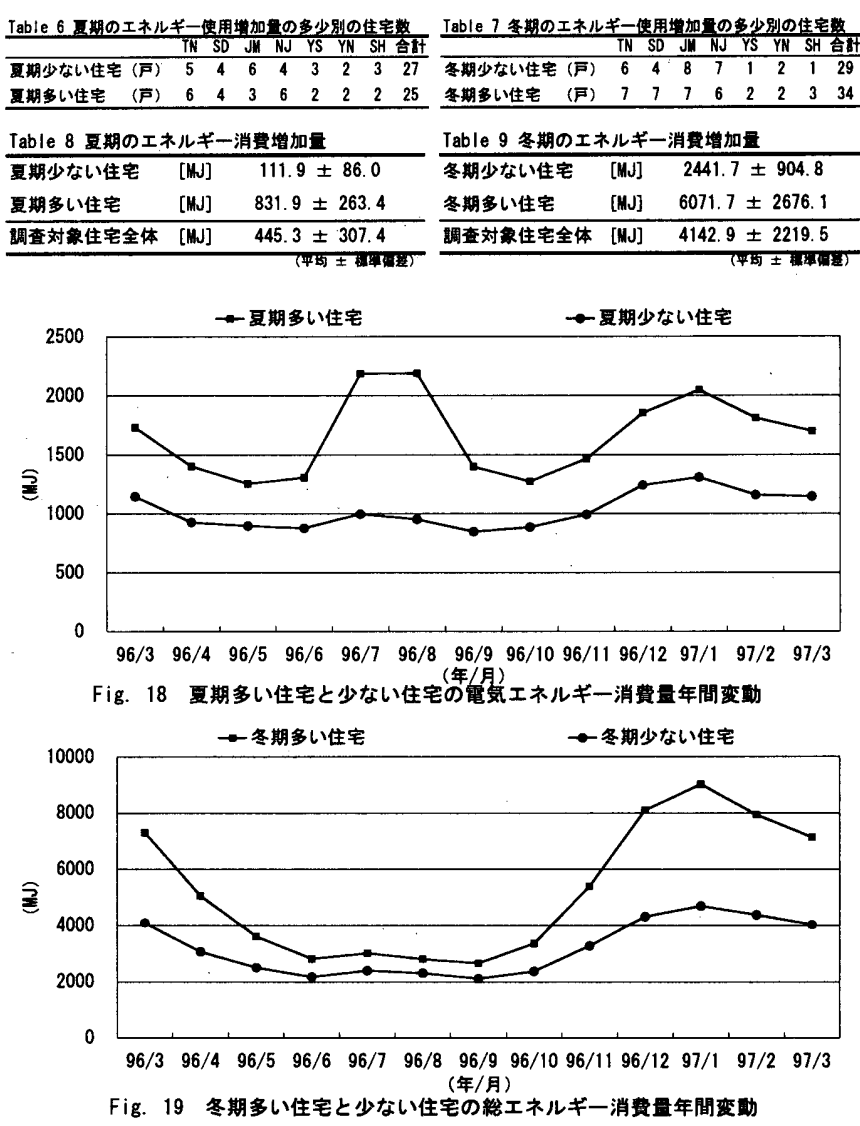

数と「冬期少ない住宅」数を示す. Table 8 に「夏期多い住宅」,

「夏期少ない住宅」および調査住宅全体の夏期のエネルギー消費増 加量の算出結果を示す. Table 9 に「冬期多い住宅」, 「冬期少ない 住宅」および調査住宅全体の冬期のエネルギー消費增加量の算出結 果を示す。 
平均夏期エネルギー消費增加量は，「夏期多い住宅」は $831.9 \mathrm{MJ}$,

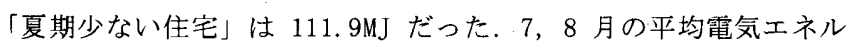
ギー消費量は，「夏期多い住宅」が 2184. 3MJ に対して，「夏期少な い住宅」は 973.5MJ と半分以下だった。また「夏期少ない住宅」 は「夏期多い住宅」と比較して, 年間を通して電気エネルギー消費 量が少なかった（Fig. 18）。「夏期多い住宅」の平均年間電気エネ ルギー消費量が $21.6 \mathrm{GJ}$ に対して，「夏期少ない住宅」は $13.7 \mathrm{GJ}$ と かなり少なかった。「冬期多い住宅」の平均冬期エネルギー消費増 加量は,「冬期少ない住宅」は $2441.7 \mathrm{MJ}$,「冬期多い住宅」は 6071.1MJ だった．12，1月の平均総エネルギー消費量は，「冬期多 い住宅」が 8560.5MJ に対して，「冬期少ない住宅」は 4511.2MJ だ った。また，「冬期少ない住宅」は年間を通して総エネルギー消費 量が少なかった（Fig，19）。平均年間総エネルギー消費量は，「冬 期多い住宅」は $68.2 \mathrm{GJ}$, 「冬期少ない住宅」は 41.8GJだった。

\section{2. 夏期のエネルギー消費増加量と意識・住まい方との関係}

「夏期少ない住宅」は，「夏期多い住宅」より，冷房の使用を控 える割合が大きかった（Fig，20）。控える理由は，「健康上良くな い」や「電気代がかさむ」と，健康面や経済面を配慮したものが多 かった。健康面や経済面以外の理由では，「扇風機で十分」が「夏 期多い住宅」よりも多かった（Fig. 21）。夏の理想的な住居内の環 境について,「夏期多い住宅」では「必要な時にはどの部屋も冷房 できるようにしておく」と「冷房する部屋としない部屋に分けてお く」が多かった。一方，「夏期少ない住宅」では「泠房せずに自然 の通風だけで過ごす」が多かった（Fig．22）。また，「夏期少ない 住宅」では, 「夏期多い住宅」と比較して, 扇風機を「比較的涼し い日に」と「クーラーと同時に」使用寸る割合が小さかった。その 一方で「クーラーを使わずに扇風機のみ使用」が多かった（Fig. 23）。また，「夏期多い住宅」が暑さをしのぐために「クーラー，扇 風機を使う」のに対して，「夏期少ない住宅」では「通風のため空 や屝を開放」が最も多かった（Fig. 24），以上より，「夏期少ない 住宅」では，「夏期多い住宅」よりも冷房の使用をより控えており， 通風や扇風機をより積極的に利用していた.

\section{3. 冬期のエネルギー消費増加量と意識・住まい方との関係}

冬期の理想的な暖房範囲は,「冬期多い住宅」では「家の中全 体」が最も多かったのに対して，「冬期少ない住宅」では「よくい る部屋だけ」が最も多かった（Fig. 25）。「冬期少ない住宅」では, 「冬期多い住宅」よりも暖房範囲を限定する傾向があった。また， 理想的な暖房時間は，「冬期少ない住宅」では，「冬期多い住宅」よ り「常時」が少なく、「寒いときだけ」の割合が多かった（Fig. 26)。「冬期少ない住宅」では，「冬期多い住宅」よりも暖房時間を より短くする傾向があった，暖房時の居間の温度分布について， 「冬期多い住宅」では「どの部分でも十分に暖かい」が半数強を占 め,「寒い部分と暖かい部分の差がはっきりしている」が残りの半 数弱を占めた。一方の「冬期少ない住宅」では，「冬期多い住宅」 より「どの部分でも十分に暖かい」と「寒い部分と暖かい部分の差 がはっきりしている」が少なく、代わって「どの部分でもやや寒 い」が約 1/3 を占めた (Fig. 27). しかし, 家の中の寒さについて 「感じることはよくあるが気にならない」が最も多かった（Fig.
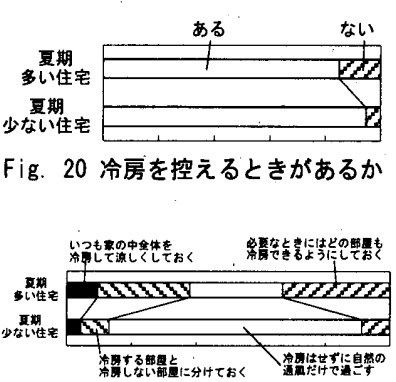

Fig. 22 夏の理想的な住居内の環境

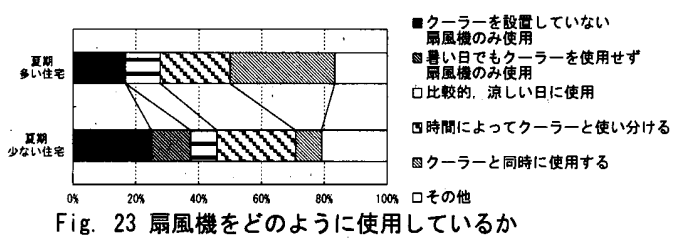

Fig. 20 冷房を控えるときがあるか

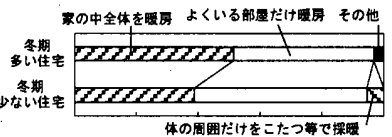

Fig. 25 理想的な暖房範囲

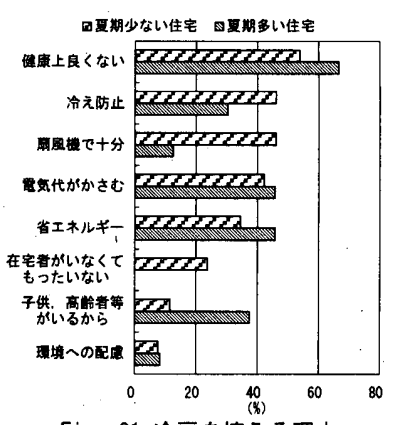

Fig. 21 冷房を控える理由

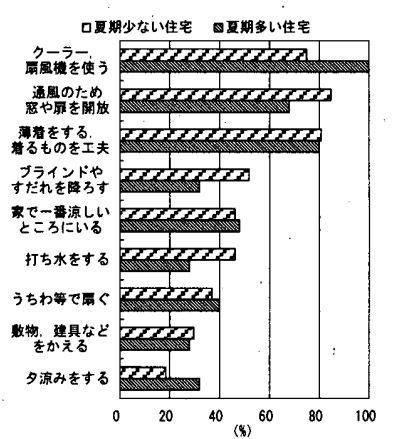

Fig. 24 夏の暑さをしのぐためのエ夫

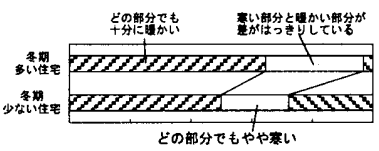

Fig. 27 囬房時のLDKの温度分布の拣子

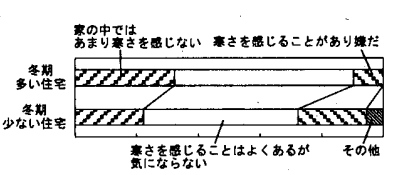

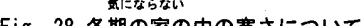

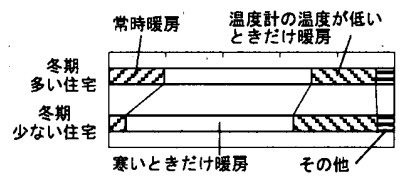

Fig. 26 理想的な暖房時間

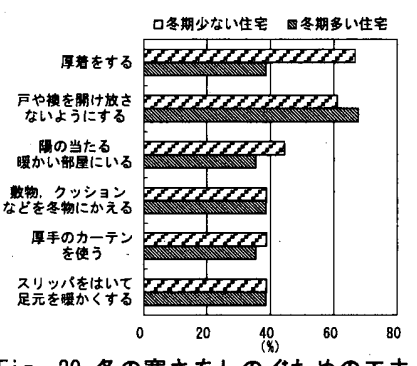

28)。どちらの住宅群でも寒さをしのぐため住まい方を工夫してい るが，特に「冬期少ない住宅」では，「冬期多い住宅」よりも「厚 着」が多かった（Fig. 29）。これらのことから，「冬期少ない住 宅」では「冬期多い住宅」よりも，暖房範囲を限定したり暖房時間 を短くしたりして暖房をより控えており，そのために暖房時の居間 で「暖かい」と感じる割合は減少し，それどころか「どの部分でも やや寒い」と感じる世帯さえあった。しかし, 家の中の寒さを気に しておらず，寒さをしのぐために着衣を調節していた。

\section{5. まとめ}

住宅のエネルギー消費量と居住者の意識・住まい方の実態を明 らかにし, 夏期, 冬期のエネルギー消費增加量に影響を及ぼす意 識・住まい方の違いについて明らかにすることを目的として，京都 市および近郊の, 都心分譲集合住宅 (TN), 都心賃貸集合住宅 （SD），郊外戸建旧省エネルギー基準対応住宅（JM），都心戸建住宅 (NJ), 郊外農家住宅（YS）, 高断熱・高気密住宅（YN），太陽熱利 
用空気集熱床暖房住宅（SH）の 7 種の形式の住宅を対象として調查 を行った。

全調査住宅の平均年間総エネルギー消費量は $49.3 \mathrm{GJ} /$ 年・戸で, 住宅種別では，TN は $38.3 \mathrm{GJ} /$ 年・戸，SD は $34.5 \mathrm{GJ} /$ 年・戸，JM は 約 $56.4 \mathrm{GJ} /$ 年・戸， NJ は約 $48.9 \mathrm{GJ} /$ 年・戸，YS は約 $88.9 \mathrm{GJ} /$ 年・戸， YN は約 59.0GJ/年・戸，SH は約 53.6GJ/年・戸であった。

夏期の電気，冬期の電気，ガス，灯油は節約されているのに対 して, 夏期のガス，灯油は節約されていなかった．夏期の電気は， 経済面と健康面の配慮から泠房を控え, 節約していた。また, 冬期 の電気，ガス，灯油は，室内で寒さを感じていながら，俟約的な意 識から暖房を控え，節約をしていた。そして，夏期の電気，冬期の 電気，ガス，灯油を節約する一方で，着衣など住まい方を工夫して いた.

住宅種別に夏期・冬期のエネルギー消費量の増加について分析 を行った，YS では断熱・気密性が低いため，冬期のエネルギー消 費量が大きく増加していた。また，SH では住宅が開放的な空間構 成であることと，居住者が家の中全体を暖房する意識が強いため, 冬期のエネルギー消費量が大きく増加していた，また，YNと JM で は居住者のクーラーへの依存度が高いため，夏期のエネルギ一消費 量が增加していた。

全調査対象住宅を夏期・冬期のエネルギー消費増加量が多かっ た住宅群と少なかった住宅群とに分類した：二つの住宅群の夏期・ 冬期のエネルギー消費増加量を示した．夏期のエネルギー消費增加 量が少ない住宅群では，多い住宅群よりも冷房の使用を控えており， 一方で通風や扇風機をより積極的に利用していた，また，冬期のエ ネルギー消費増加量が少ない住宅群では多い住宅群よりも暖房をよ り控えており，そのために暖房時の居間で「どの部分でもやや寒 いと感じる世帯さえあるが，家の中の寒さをそれほど気にしてお らず，寒さをしのぐために着衣を調節していた。

\section{謝辞}

本研究にご協力いただいた調査対象住宅の居住者の皆様, 京都 府立大学生活科学部住居環境学研究室（当時）の方々に感謝します. 尚，本研究の一部に平成 8 年度文部省科学研究費補助金基盤研究

（B）（2）（代表 松原斎樹 課題番号 08455273）の援助を受けた.

注）各月の使用量データの欠損は，前後の月の使用量の平均値を用いて推定した

\section{参考文献}

1）尾島俊雄ほか：住宅におけるエネルギ消費の実態調查 第 3 報一エネルギ消費実態に 関する実態調查 (1) 一統計資料の解析と質問紙調查の概要一，空気調和・衛生工学 会論文集, No. 12 , pp. $53-65,1980.2$

2）尾島俊雄ほか：住宅におけるエネルギ消費の実態調查，第 4 報一エネルギ消費実態 に関する実態調査（2）－冷暖房・給湯設備の実態とエネルギ消費量一, 空気調和・ 衛生工学会論文集, No. 12 , pp. $67-80,1980.2$

3）坂口淳ほか：新潟市に建設された住宅における室内温熱環境とエネルギー消費量に閏 する実測調查, 全電化・高気密・高断熱住宅を対象として, 日本建筑学会計画系論文 集, No. 543 , pp. 33-39, 2001.5

4）佐々木淑贵ほか：户建住宅における電気エネルギー消費に関する研究，主に東北地方 を対象とした太陽光発電の有効性の検討，日本建築学会計画系論文集，№． $545 ， p p$.
$79-86,2001: 7$

5）依田浩敏ほか：環境共生型集合住宅にお计るエネルギー・水消費量の実態調查，日本 建筮学会計画系論文集, No. 549 , pp. $67-74,2001.11$

6）三浦秀一：全国における住宅の用途別エネルギー消費と地域特性に関する研究，日本 建筑学会計画系論文集, No. 510, pp. 77-83，1998.8

7）三浦秀一：全国都道府県庁所在都市の住宅におけるエネルギー消費と $\mathrm{C} 02$ 排出量の推 移に関する研究，日本建築学会副画系論文集，No. 528，pp，75-82，2000.2

8）三浦秀一ほか：日本の住宅における地域別エネルギー需要構造とその増加要因に関す る研究, 日本建築学会計画系論文集, No. 562, pp. 105-112, 2002.12

9）石田建一ほか：户建住宅のエネルギー消費量、日本建築学会計画系論文集，No，501， pp. $29-36,1997.11$

10）田中昭雄ほか：住宅種別用途別エネルギー消費量推定に関する研究，日本建築学会 計画系論文集, No. 539 , pp. 67-74，2001.5

11）松原斎樹ほか：冬季の住宅居間の熱環境と居住者の意識·住まい方その1。調査の 概要, 日本建築学会近㙨支部研究報告集, 第 32 号計画系, pp. $21-24,1992.6$

12）澤島智明ほか：冬季の住宅居間の熱環境々居住者の意識・住まい方その 2. 暧房機 器使用と生活行為の関係, 日本建築学会近畿支部研究報告集, 第 32 号 計画系, pp. $25-28,1992,6$

13）松原斎樹ほか：冬期の住宅居間の熱環境と居住者の意識·住まい方その3．居住者 による環境形成と評価のモデル化，日本建築学会大会学術講演梗概集，pp．449-450， 1992.8

14）松原斎樹ほか：京都市近辺地域における冬期住宅居間の熱環境と居住者の住まい力 に関する事例研究〜暖房機器使用の特徵と団ら九時の起居様式〜，日本建築学会計画 系論文集，No，488，pp，75-84，1996.10

15）日本国：「気候変動に関する国際連合枠組条約」に基づく第 3 回日本国報告書，2002。

16）絵内正道ほか：居住者の温熱镶境の実態その1. 寒さに応じた住い方と室温変動 パターンについて，日本建築学会論文報告集，第 264 号, pp. 91-97，1978.2

17）絵内正道ほか：居住者の温熱環境の実態その 2 ．寒さに忍じた住い方と室温設定 について，日本建築学会論文報告集，第 265 号，pp，105-113，1978.3

18）絵内正道ほか：居住室の温熱瑔境の実態 その3.寒さに応じた住い方と熱消費量 について, 日本建築学会論文報告集, 第 266 号, pp. 97-103

19）足立直之ほか：住宅におけるエネルギー消費量と住まい方に関する実態調查 新潟 市におけるエネルギー需要構造に関する研究 その 1 , 日本建築学会計画系論文集, No. 465 , pp. $49-59,1994.11$

20）吉野博ほか：熱環境からみた冬期の居住性能に関する地域特性の変化一東北地 方都市部を対象とした 10 年前の調查との比較一, 日本建築学会計画系論文集, No. 499 , pp. $1-7,1997.9$

21）長谷川兼一ほか：東北地方における断熱気密住宅のエネルギー消費聂一暖房用を 中心とした実態調査と数値計算一，日本建築学会計画系論文集，No．557，pp．49$56,2002.7$

22）澤地孝男ほか：暖冷房行為生起の決定要因と許容室温範囲に関する検郡 住宅の窒 内気候形成に寄与する居住者の行動に関する研究その 1 , 日本建築学会論文報告集， 第 382 号, pp. 48-58, 1987.12

23）澤地孝男ほか：住宅における生活行為の時刻変化（主婦の場合）住宅の室内気㬋 形成に寄与する居住者の行動に関する研究 その 2 , 日本建築学会論文報告集，第 398 号, pp. $35-46,1989.4$

24）澤地孝男ほか：住宅に扩ける生活行為の時刻変化（主人と子供の場合）住宅の室 内気候形成に寄与する居住者の行動に関する研究 その3，日本建築学会諭文報告集， 第 404 号, pp. $23-36,1989.10$

25）洪元和：集合住宅にお汁る住戸属性と年間エネルギー消費量の分析，日本建築学会 計画系論文報告集, No. 445, pp. $53-61,1993.3$

26）鈴木憲三ほか：札㹸，京都，那羁の公営集合住宅における暖冷房環境の比較分析 暖椧房使用に関する意識と住まい方の地域特性と省エネルギー対策の研究 その 1 , 日本建築学会計画系論文集，No. $475 ， p p ． 17-24 ， 1995.9$

27）坊垣和明ほか：夏期および冬期の居住室室温とその地域性に関する研究，一全国的 調查に基づく住宅のエネルギー消費量とライフスタイルに関する研究一第 2 報、日本 建築学会計画系論文集, No. 505, pp. 23-30, 1998.3

28）坊垣和明ほか：全国的調査に基づく住宅の暖冷房時間および暖冷房期間に関する研 究，日本建築学会計画系論文集；No．509，pp．41-47，1998.7

29）福島适成ほか：九州地区にお汀る住宅エネルギー消費構造に関する研究，空気調 和・衛生工学会綸文集, No. $57, \mathrm{pp}, 35-47,1995.2$

30）佐々问美ほか: 省エネルギーの意識と住まい方に関する調查研究 一奈良市近郊の 新興住宅地の戸建住宅を対象とした場合一, 日本家政学会誌, Vol. 54 No. 11, pp 935-943, 2003.

31）森教子ほか：エネルギー供給形態の異なる戸建住宅のエネルギー消費量と節約行為 による省エネルギー効果に関する研究，日本建築学会計画系論文集，No，565，pp. $99-106,2003.3$

32）石田秀樹ほか：開放系住居の夏の噮境特性 町家の冷気積層型の上方開放空問， 日 本建築学会計画系論文報告集，第 408 号, pp. 23-31，1990.2

33）花岡利昌：伝統民家の生態学, 海青社, 1991.6

34）富川修ほか：太陽熱利用空気集熱式床暖房住宅に関する住まい方䛯查，日本建築学 会大会学術講演梗概集 環境工学 (2), D-2, pp.425-426, 1996.9

35）長谷川兼一ほか：太陽エネルギーを利用した各種住宅の熟環境特性とエネルギー消 費量その 1. 冬季のアンケート調查及び実測調查, 日本建築学会大会学術講演梗概 集 環境工学 (2), pp. 247-248, 2002.8

36）澤地孝男ほか：用途別エネルギー消費量原単位の算出と推定式の作成 全国的調查 に基づく住宅のエネルギー消費とライフスタイルに関する研究（第 1 報），白本建築 学会敦画系論文集, No. 462 , pp. 41-48, 1994.8

37）澤島智明ほか：関西地域におけるプレハブ住宅の冬期温熱環境と居住者の住まい力 に関寸る事例研究，日本建築学会計画系論文報告集，No，554，pp．69-76，2002.4

(2004年 4 月 10 日原稿受理, 2004 年 9 月 16 日採用決定） 